\title{
PRELIMINARY ASSESSMENT OF PARTICULATE CONCENTRATION NEAR COAL FIRED POWER PLANT
}

\author{
BOGDANA VUJIĆa, VASILE PODE ${ }^{b}$, JELENA MIĆIĆ ${ }^{a}$, \\ FRANCISC POPESCU ${ }^{\star}$, UNA MARČETA ${ }^{a}$, ADRIAN EUGEN CIOABLA $^{c}$
}

\begin{abstract}
This study shows the results of preliminary monitoring of particulate matter (PM10 and PM2.5) at four measurement points, during the three campaigns (spring, autumn, winter) The study was conducted for the first time in residential area near coal-fired power plant, Ugljevik, Bosnia and Herzegovina. The power plant flue gas cleaning equipment in the time of this research was out of the function. Authors investigated seasonal variations of PMs concentration levels, influence of terrain structure and meteorological condition on PMs distribution and identification of PMs origin sources. The results revealed that seasonal variation was more expressed in the case of PM2.5 concentration, while for PM10, occasionally episodic pollution $(399 \mu \mathrm{g} / \mathrm{m} 3)$ was recorded. Also, it was noted that prevailing meteorological conditions and surrounding terrain structure could have limiting effect on PMs dispersion. In order to detect PMs origin, linear regression analysis was applied. Authors revealed that PM2.5 originating from power plant could be prescribed partly for $\mathrm{M} 1$ where the greatest correlation was calculated $\left(R^{2}=0,45\right)$. Although the measuring sites were set in proper position regarding dominant winds and terrain structure, it was identified that certain measurement sites were affected by the other local particulate matter sources, especially in case of PM10.
\end{abstract}

Key words: particulate matter, PM2.5, PM10, air quality assessment, large combustion plants

\section{INTRODUCTION}

Particulate matters (PMs) in ambient air represent one of the most critical pollutants worldwide regardless of whether the area is industrial or urban. PMs are present in the air in various shapes and sizes, ranging from less than $10 \mathrm{~nm}$ to $10 \mu \mathrm{m}$ in aerodynamic diameter [1].

a University of Novi Sad, Technical Faculty "Mihajlo Pupin" Zrenjanin, Serbia

b University Politehnica Timisoara, Faculty of Industrial Chemistry, Timisoara, Romania

c University Politehnica Timisoara, Faculty of Mechanical Engineering, Environmental Engineering,

Timisoara, Romania

*Corresponding author: francisc.popescu@upt.ro 
High PMs concentrations in air, along its negative impact on the environment can also have an impact on human health and could cause chronic respiratory diseases [2]. Health disorder also depends on the size of PMs, exposure time to PMs as well as on population age [3]. Hence, coarse

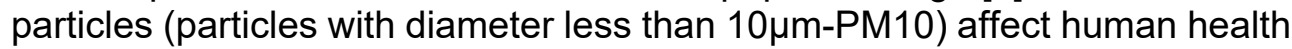

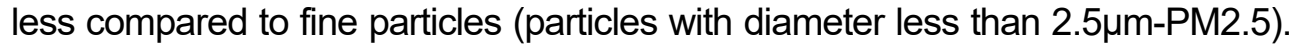
The origin of these two groups of PMs could be different. While PM10 is defined as a primary pollutant, which means that it is emitted directly from natural or anthropogenic source, PM2.5 is defined as a secondary pollutant that occur in complex and uncertain atmospheric processes. In physic-chemical reactions of PM2.5 formations, the main role belongs to the sulfur-dioxide $\left(\mathrm{SO}_{2}\right)$, nitrous oxides $\left(\mathrm{NO}_{\mathrm{x}}\right.$ ) and Volatile Organic Compounds (VOC) [4]. Those gasses are responsible for the secondary particle formations in three steps: nucleation, condensation and coagulation [5]. Nucleation is the first step that is the most probable in the presence of the sulfuric acid $\left(\mathrm{H}_{2} \mathrm{SO}_{4}\right)$ that is prone to form hydrogen bond with other atmospheric compounds (water, ammonia, organic acids, etc.) [6]. In the condensation phase, the most occurring process is merging of gas pollutants with the existing solid particle in the air. The next, and the final phase, is mutual aggregation of previously mentioned forms that leads to the particle size growth.

Since the reactions of particle formation in the atmosphere are very complex there is no universal chemical reaction to describe it. The basic mechanism for forming PM2.5 and other atmospheric aerosols is oxidation of gas phase $\mathrm{SO}_{2}$ or $\mathrm{NO}_{2}$ by hydroxyl radicals $\left(\mathrm{OH}^{-}\right)$and formation of sulfur and nitrous acid $\left(\mathrm{H}_{2} \mathrm{SO}_{4}\right.$ and $\left.\mathrm{HNO}_{3}\right)$ and further interaction of these products [7]:

$$
\begin{gathered}
\mathrm{SO}_{2}+\mathrm{OH}^{\cdot} \rightarrow \mathrm{HSO}_{3}^{-} \\
\mathrm{HSO}_{3}+\mathrm{O}_{2} \rightarrow \mathrm{SO}_{3}+\mathrm{HO}_{2} \\
\mathrm{SO}_{3}+\mathrm{H}_{2} \mathrm{O}+\mathrm{M} \rightarrow \mathrm{H}_{2} \mathrm{SO}_{4} \\
\mathrm{H}_{2} \mathrm{SO}_{4}+\mathrm{NH}_{3} \rightarrow \mathrm{NH}_{4} \mathrm{SO}_{4} \\
\\
\mathrm{NO}_{3}+\mathrm{O}_{3} \rightarrow \mathrm{NO}_{2}+\mathrm{O}_{2} \\
\mathrm{NO}_{2}+\mathrm{OH}^{-} \rightarrow \mathrm{HNO}_{3} \\
\mathrm{HNO}_{3}+\mathrm{NH}_{3} \rightarrow \mathrm{NH}_{4} \mathrm{NO}_{3} \\
\\
\mathrm{SO}_{2}+2 \mathrm{NO}_{2}+2 \mathrm{H}_{2} \mathrm{O} \rightarrow 2 \mathrm{H}^{+}+\mathrm{SO}_{4}{ }^{2-}+2 \mathrm{HONO} \\
2 \mathrm{NH}_{3}+\mathrm{SO}_{2}+2 \mathrm{NO}_{2}+2 \mathrm{H}_{2} \mathrm{O} \rightarrow 2 \mathrm{NH}_{4}+\mathrm{SO}_{4}{ }^{2-}+2 \mathrm{HONO} \\
\left(\mathrm{VOC}_{+} \mathrm{OH}^{-}\left(\text {or } \mathrm{O}_{3}\right) \rightarrow \text { highly oxygenated molecules }\right)
\end{gathered}
$$

A scheme of secondary particle formation in atmosphere is given in Figure 1. 


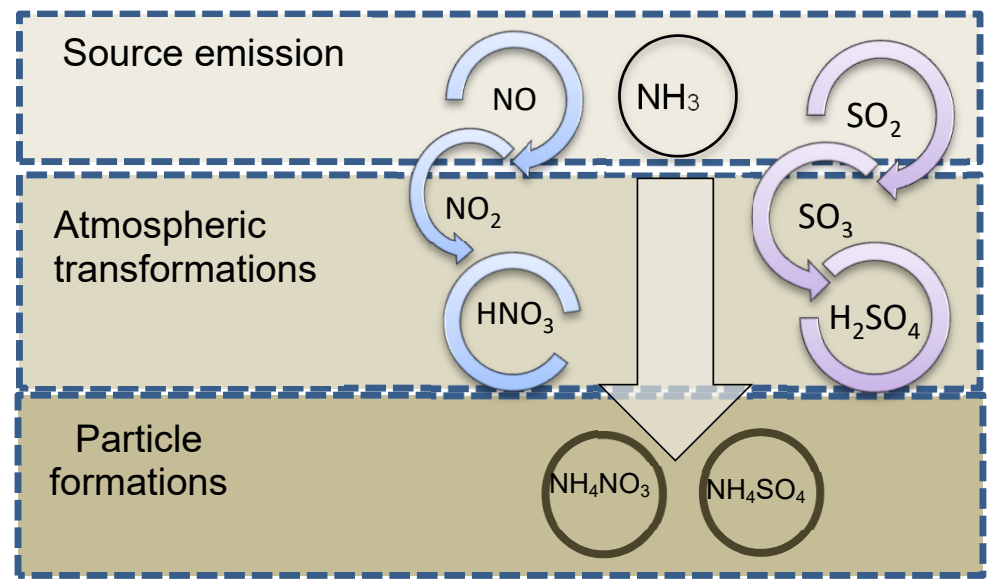

Figure 1. Forming of PM2.5 and other atmospheric aerosols is oxidation of gas phase $\mathrm{SO}_{2}$ or $\mathrm{NO}_{2}$ by hydroxyl radicals $\left(\mathrm{OH}^{*}\right)$

Having in mind that the origins of fine particulates are complex atmospheric processes, it is more likely to happen in the presence of emission sources that discharge precursors of PM2.5 (e.g. combustion processes of fossil fuels) [8]. The occurrence of higher PMs concentration because of Large Combustion Plants (LCP) operation was reported by many studies [9].

There are nine coal fired LCP in the territory of Bosnia and Herzegovina $(\mathrm{BiH})$. Most of the LCPs were built during the seventies in $20^{\text {th }}$ century. In the area of Ugljevik municipality $(\mathrm{BiH})$ there is a coal (with sulfur content $3-6 \%$ ) fired thermal power plant with one boiler of $350 \mathrm{MW}$ capacity which was constructed in 1983. The average annual electricity production of this LCP is $1560 \mathrm{GWh}$. The average PM10 emission concentration is $383\left(\mathrm{mg} / \mathrm{Nm}^{3}\right)$ [10]. The treatment of waste gases is carried out by two Electrostatic Precipitators (EPs), which are in poor condition despite the frequent maintenance. The new electrostatic precipitators reconstruction has begun in 2017 [11]. Hence, LCP Ugljevik generates higher amounts of PM2.5 (373 t) than other plants. For example, LCP "Nikola Tesla" B1/B2 in Serbia generates 290t and LCP Kostolac B1/B2 in Serbia generates 32t.The LCP in Ugljevik is one of the main air pollutants in Bosnia and Herzegovina [12].

The emissions from LCP Ugljevik contribute to the poor air quality within the wider area and constant citizens' complaints. As a first step in improving air quality management as well as enforcement of the national legislation that is harmonized with EU directives [13], the municipality of Ugljevik provided preliminary ambient air quality assessment. For the first time, three monitoring campaigns at four monitoring sites near LCP were conducted. The concentration 
of sulfur dioxide (SO2), nitrogen oxides (NOx), fine (PM2.5) and coarse (PM10) particles, carbon monoxide $(\mathrm{CO})$, ozone $\left(\mathrm{O}_{3}\right)$ as well as meteorological parameters were measured.

Due to poor condition of EPs at Ugljevik LCP, this study was focused solely on coarse and fine particle monitoring. Thus, according to the obtained monitoring data for the first time, the PMs assessment in LCP surrounding was performed. The assessment was based on detailed data analysis and identifying: 1) the seasonal variations of PMs concentration levels, 2) influence of terrain structure and meteorological condition on PMs distribution and 3) PMs source origin. The results and conclusions obtained within this study is a good starting point in understanding the PMs atmospheric fate in this area which could help decision-makers to undertake necessary control measures for air quality improvement.

\section{RESULTS AND DISCUSSION}

In order to present all data of this extensive PMs monitoring that comprehended three campaigns over large periods of time, at four measurement sites, in this paper, all daily PMs concentrations are presented in the graph form (Figure 2 and Figure 4). Additionally, the statistical data on PMs concentrations are presented in the form of boxplots (Figure 3 and Figure 5.

\section{Assessment of seasonal variation of PMs concentration levels}

Daily PM10 concentration levels during all three campaigns at all sites are presented in Figure 2.

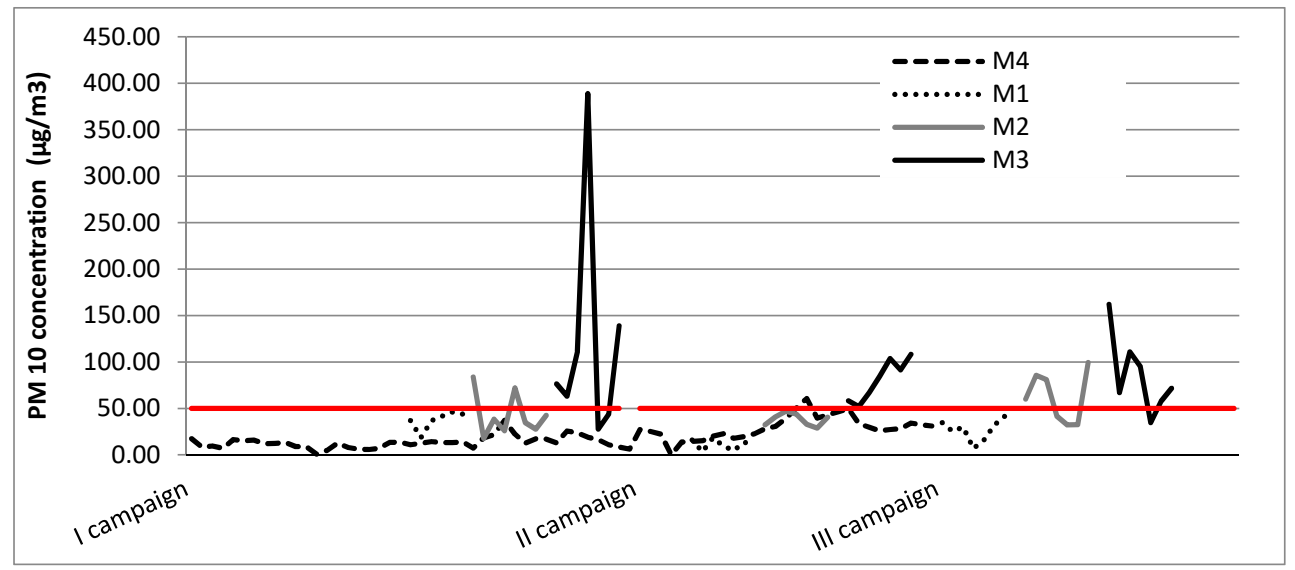

Figure 2. Data on PM10 concentration levels on all sites (M1-M4) during three campaigns 


\section{PRELIMINARY ASSESSMENT OF PARTICULATE CONCENTRATION NEAR COAL FIRED POWER PLANT}

The measurement results have shown that daily PM10 concentration levels during all three campaigns at $\mathrm{M} 1$ did not exceed the limit value $\left(\mathrm{LV}=50 \mu \mathrm{g} / \mathrm{m}^{3}\right)$ [13]. During the II campaign, at M2, there has been an exceedance of the limit value (LV) in $60 \%$ of samples (maximum concentration was $99,51 \mu \mathrm{g} / \mathrm{m}^{3}$ ), as well as in $30 \%$ of samples during the III campaign at the same measurement site (maximum concentration was $83,93 \mu \mathrm{g} / \mathrm{m}^{3}$ ). At $\mathrm{M} 3$, higher PM10 concentration levels were noted than at the other sites. Depending on the campaign, the LV exceedance ranged from $71 \%$ to $100 \%$ of samples at M3. The maximum concentration was measured during the II campaign $\left(399.95 \mu \mathrm{g} / \mathrm{m}^{3}\right)$. PM10 concentration levels at M4 were significantly lower during the I campaign compared to the II campaign when three exceedances of the mean daily values were noted. During the III campaign, data coverage of PM10 concentration at M4 was less than $90 \%$, so it was not considered in this paper. For each campaign, the highest PM10 concentrations were measured at M2 and M3 (Figure 3).

Figure 3 presents statistical data on PM10 concentration during the monitoring campaigns. The boxes represent 1st and 3rd quartile, the whiskers represent minimum and maximum values, the asterix represents outlier values and the red line represents the daily limit value $\left(50 \mu \mathrm{g} / \mathrm{m}^{3}\right)$.

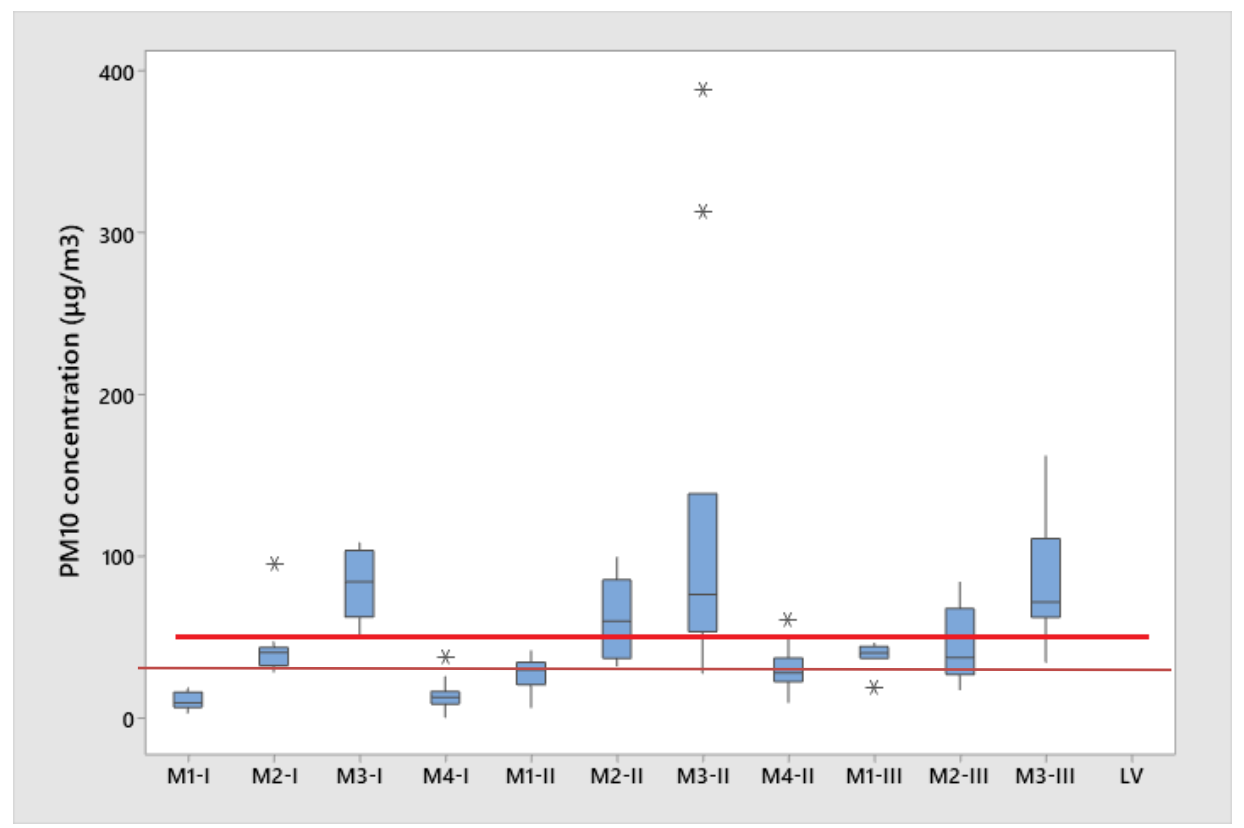

Figure 3. Box plot showing the PM10 distribution during the measuring campaign for all three measurement seasons (I, II and II season). 
Daily PM2.5 concentration levels during all three campaigns at M1M3 are presented in Figure 4.

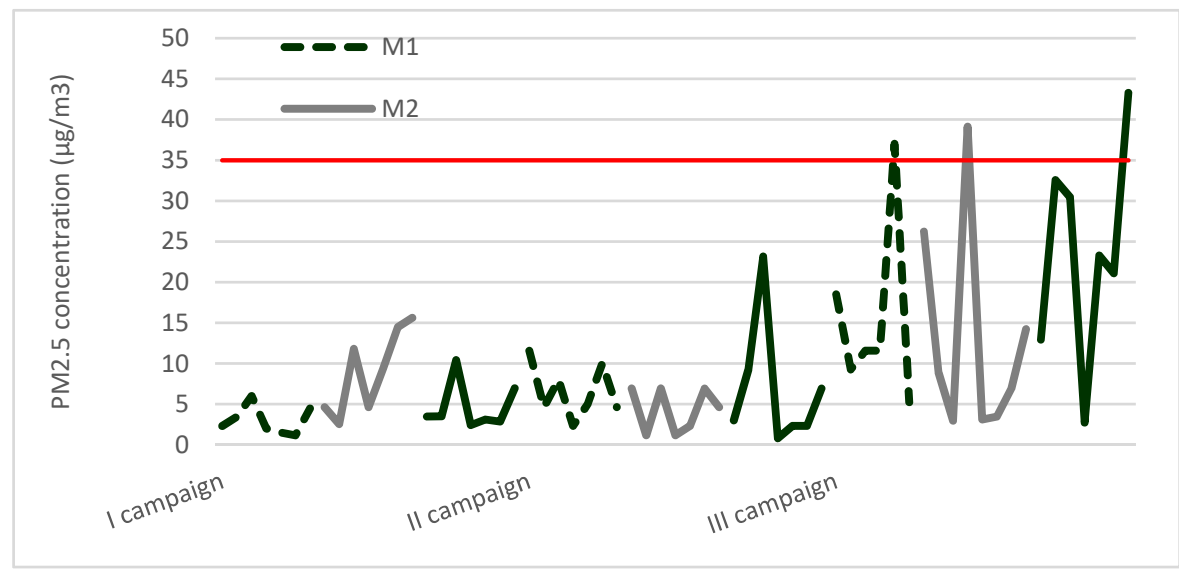

Figure 4. Data on PM2.5 concentration levels on sites M1-M3 during three campaigns

The statistical data of the measured PM2.5 concentrations for all measuring sites during the three campaigns are given in the form of box plots (Figure 5). During the III campaign, PM2.5 concentrations exceeded the LV of $35 \mu \mathrm{g} / \mathrm{m}^{3}$ [13] at all measuring sites (M1, M2 and M4). The maximum concentration of $43.3 \mu \mathrm{g} / \mathrm{m}^{3}$ was noted at M4 during the III campaign. In general, PM2.5 concentrations at all three sites were higher in the III campaign when compared to the I and the II campaign.

Figure 5 presents statistical data on PM2.5 concentration during the three monitoring campaigns. The boxes represent 1st and 3rd quartile, the whiskers represent the minimum and maximum values; The asterix represents outlier values; The Red line represents daily limit value $(35 \mu \mathrm{g} / \mathrm{m} 3)$.

Regarding seasonal variation of PMs concentration, it could be concluded that PM2.5 concentration showed significantly higher fluctuation during campaigns. Hence, during the winter PM2.5 concentration is much higher in comparison to the spring and autumn season which supports the conclusion that PM2.5 originates from LCP that was operating harder during the colder seasons. PM10 concentration fluctuation was not expressed to ahigh extent during the seasons. However, occasionally episodic pollution by PM10 was recorded. 


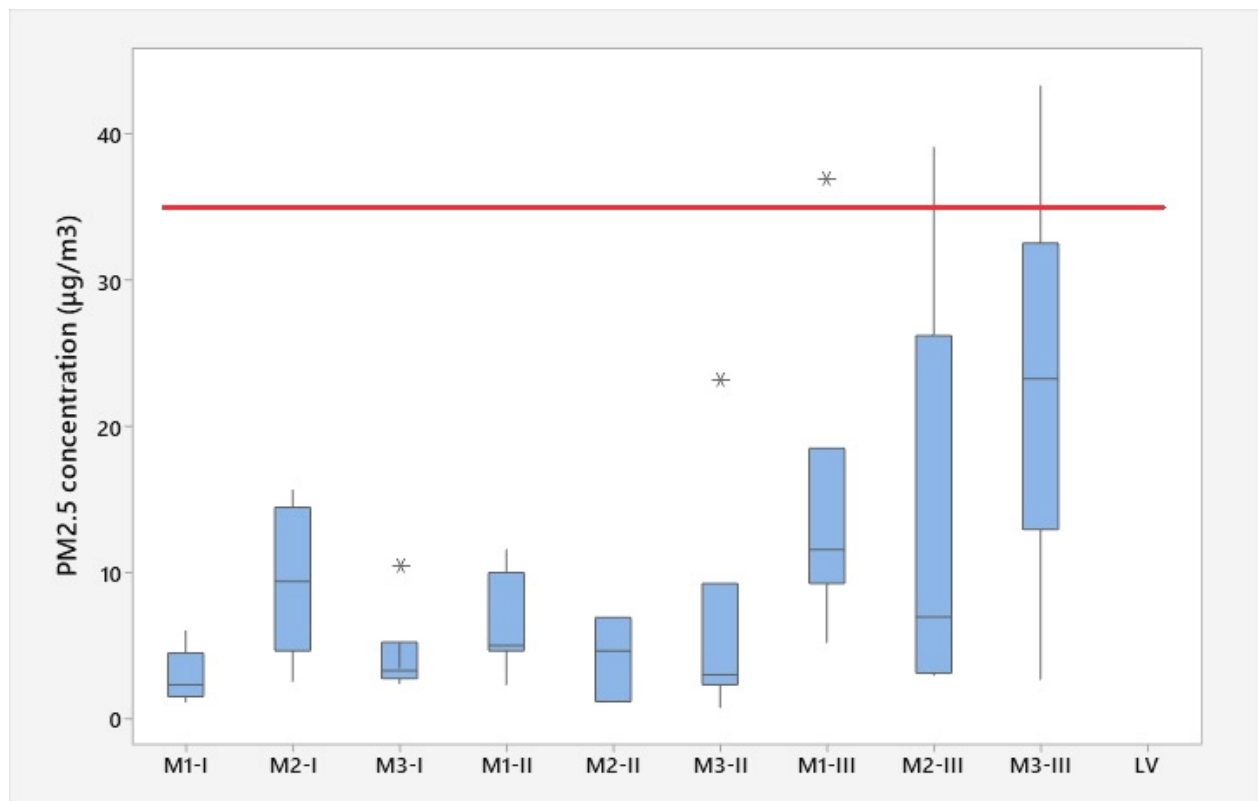

Figure 5. Box plot showing the PM2.5 distribution during the measuring campaign for all three measurement seasons (I, II and II season).

\section{Influence of topography and meteorological parameters on PMs distribution}

The fate of atmospheric pollutants is affected by numerous factors such as emission source properties, pollutant and environmental characteristics where it is being released (topography, meteorological conditions etc.). All abovementioned factors are correlated and cannot be observed separately. Thus, taking into account the topography of Ugljevik environment which is a hilly landscape with slight elevations and valleys in the range of $150-400 \mathrm{~m}$ above the sea level on one hand and the height of the LCP emission source $(300 \mathrm{~m})$ on the other, undoubtedly leads to the conclusion that this area structure can have some limiting effect on the free pollutant distribution over long distances.

Considering the dominant winds, this area is characterized by winds of an average speed of up to $2 \mathrm{~m} / \mathrm{s}$. Calm periods are frequent $(308 \%$ o $)[14,15]$.

According to the data on wind speed (WS) and wind direction (WD) measured at M4 it is evident that the potential impact of the LCP on the environment is changeable. During the I and the II campaign, the most potentially impacted areas could be at north-west (NW), south-west (SW) and north-east (NE) from the LCP, while during the III campaign it could be areas at the northwest (NW) direction of the LCP (Figure 6). 

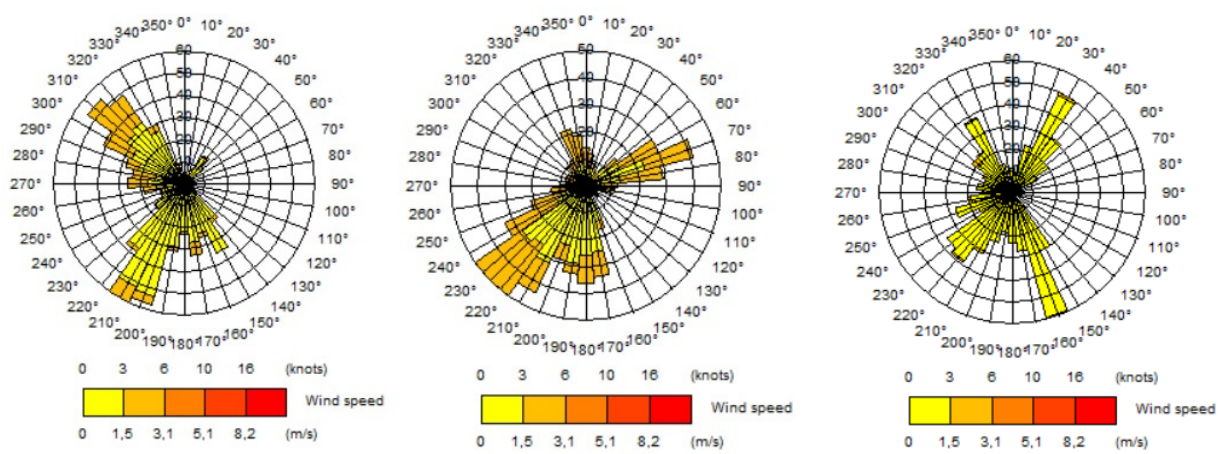

Figure 6. Wind Roses for spring (left), autumn (middle) and winter (right) campaign

On the other hand, wind speed during all campaigns was relatively low (maximum speed was lower than $2.5 \mathrm{~m} / \mathrm{s}$ ). By analyzing the relation of PM10 concentration and wind speeds, it was concluded that the maximum PM10 concentrations were measured at low wind speed (less than $1 \mathrm{~m} / \mathrm{s}$ ). Figure 7 represents the relation between wind speed and PM10 at M4 during the I campaign.

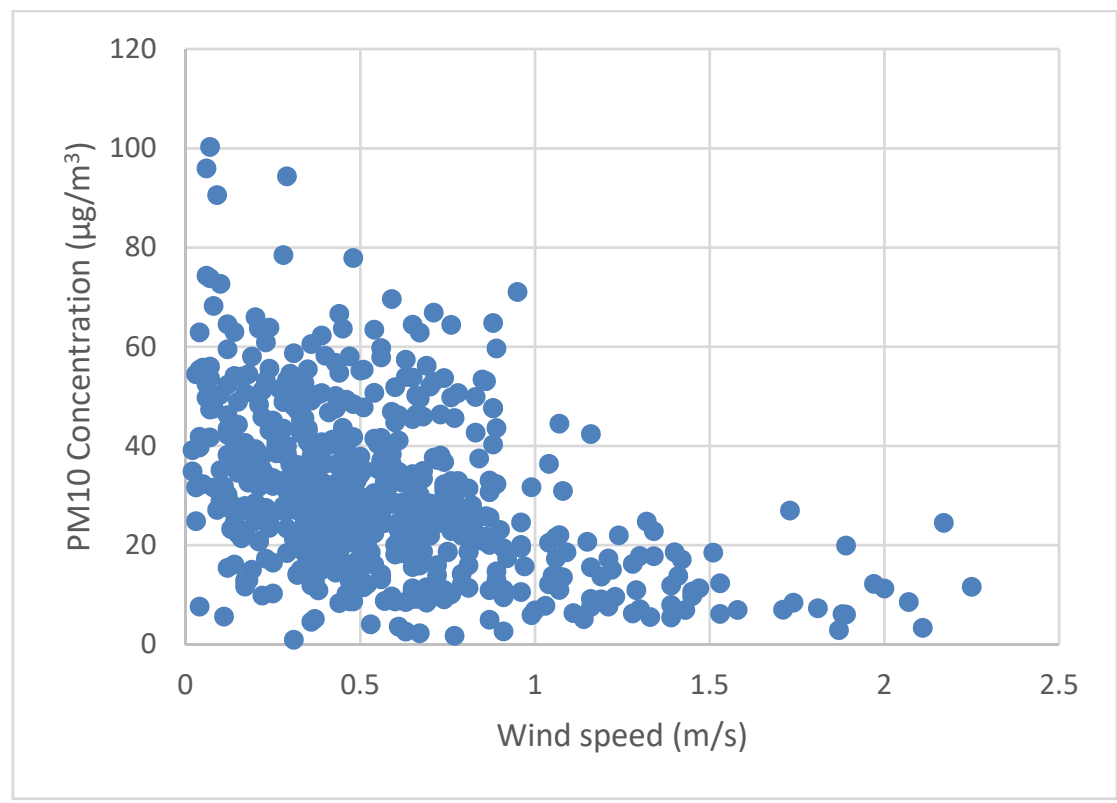

Figure 7. Relation between the wind speed and PM10 at M3 during the I campaign 


\section{PRELIMINARY ASSESSMENT OF PARTICULATE CONCENTRATION \\ NEAR COAL FIRED POWER PLANT}

Regarding dominant winds and terrain structure, all measuring sites were placed at locations which are potentially mostly influenced by the emission.

\section{The origin of the particulates}

In order to derive greater conclusions based on PMs monitoring data, authors decided to use linear regression analysis (LRA). In recent studies, researchers reported that LRA could give crucial information relating to the particle origin [16]. Hence, the relation between PM2.5 and PM10 mass concentration indicated that higher relation coefficient is attributed to anthropogenic particle sources and the higher share of fine particles, while the smaller ratios indicate the higher share of coarse particles, which might be related to natural sources [17].

In order to understand relations between PM2.5 and PM10 and their origin in this area, LRA for each measuring site by seasons was performed. The relations are determined by correlation coefficients $\left(R^{2}\right)$ that are calculated in Microsoft Excel software [18].

The results showed very different, but still very low correlation between PM2.5 and PM10 for all sites during all seasons. The highest correlation coefficient $\left(R^{2}=0,45\right)$ was calculated for $M 1$ measuring site (Figure 8$)$. On the other hand, at M3, where the highest PM10 concentration and the largest number of LV exceedance were measured, the lowest correlation was noted $\left(R^{2}<0,02\right)$. This can lead to the conclusion that there is a low probability that LCP had an influence on the measuring sites M2, M3 and M4, regarding fine particles, but the highest influence of LCP could be noted for M1.

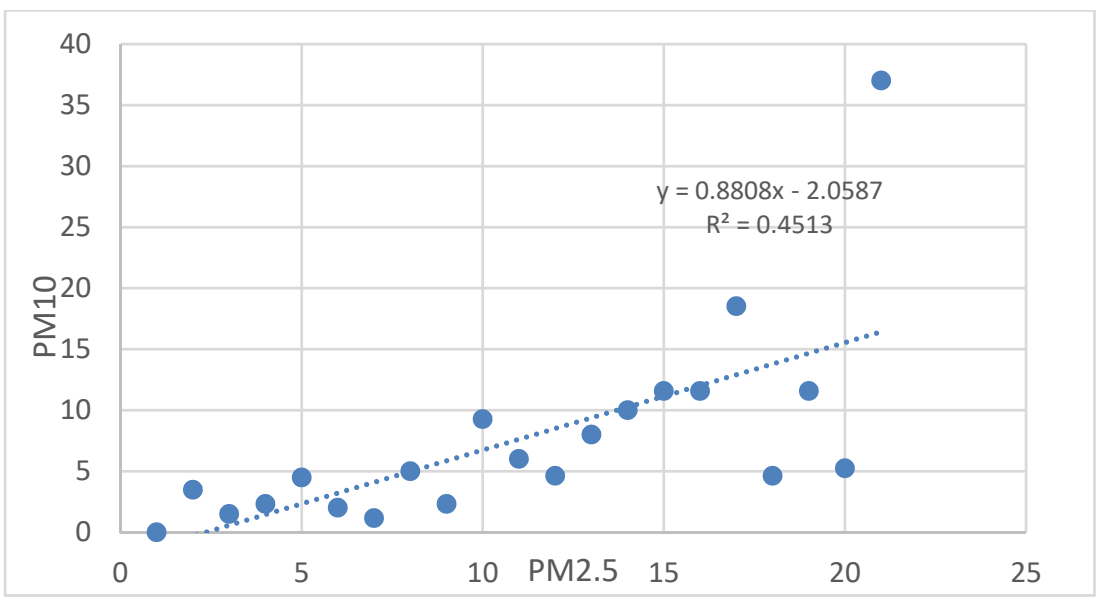

Figure 8. Linear regression analysis between PM2.5 and PM10 for M1 
Since the measuring points were set relatively close to the point source and considering the source height this could be expected [19]. The relatively weak correlation between concentrations during the seasons could also indicate the possible changes in emission rate due to overhaul, unexpected malfunctions or reduced production capacity (http://riteugljevik.com).

\section{CONCLUSION}

The air pollution represents a major problem in the vicinity of the LCP Ugljevik, $\mathrm{BiH}$. Although the authorities have harmonized legislation with the high EU air quality standards, for LCP operator it is impossible to manage all technical issues within the defined deadlines because the outdated equipment and financial restrictions for new investments. In order to access air quality in populated area around LCP, measurement of PMs concentrations at three sites during three campaigns has been conducted for the first time.

The assessment included detailed analysis of PMs concentrations, their seasonal fluctuation, the indication of possible distribution pattern and PMs source identification as well.

The results indicated that PM2.5 concentration showed intensive seasonal fluctuation, especially during the winter season. However, PM10 seasonal fluctuations were not expressed to that extent. A very high and episodic pollution $(399 \mu \mathrm{g} / \mathrm{m} 3)$ was recorded, regardless of the measuring season

Concerning the distribution pattern due to prevailing meteorological conditions and terrain structure, all measuring sites were placed at locations which could potentially be mostly influenced by the emission. Still, according to the results of LRA, where PM2.5/PM10 relation was calculated, it was noted that the PM2.5 originating from LCP had the most influence on the measuring site $M 1$ with the correlation coefficient of 0,45 . Although the authorities requested the air quality assessment for the populated area, it was noted that the measurement sites (M2 - M4) were not set at proper distances from LCP. Thus, it could be said that the impact of other sources (house heating, soil resuspension etc.) was dominant at those monitoring sites. In general, it can be concluded that the seasonal variations in concentration levels were noticeable to a certain extent.

However, this research has some limitations including a short period of time over which the trends were analyzed. Therefore, further investigation should be focused on qualitative and quantitative PMs analysis coupled with modelling of PMs dispersion into the surrounding environment. This approach could be useful as a basis for detailed air quality assessment, improvement plans, pollution control strategies, establishing representative monitoring network and a framework of health impact assessment in accordance with the WHO and EU recommendations. 


\section{EXPERIMENTAL}

\section{Monitoring domain}

The city of Ugljevik, with 15710 inhabitants [20] is in the eastern part of Bosnia and Herzegovina. The thermal power plant complex is in the vicinity of a populated place while the closest residential buildings are situated at a distance of only $200 \mathrm{~m}$. The plant is supplied with coal from its own mine located on the south of "Bogutovo Selo" complex (Figure 9) with an annual capacity of 1.75 million tons of coal [21].

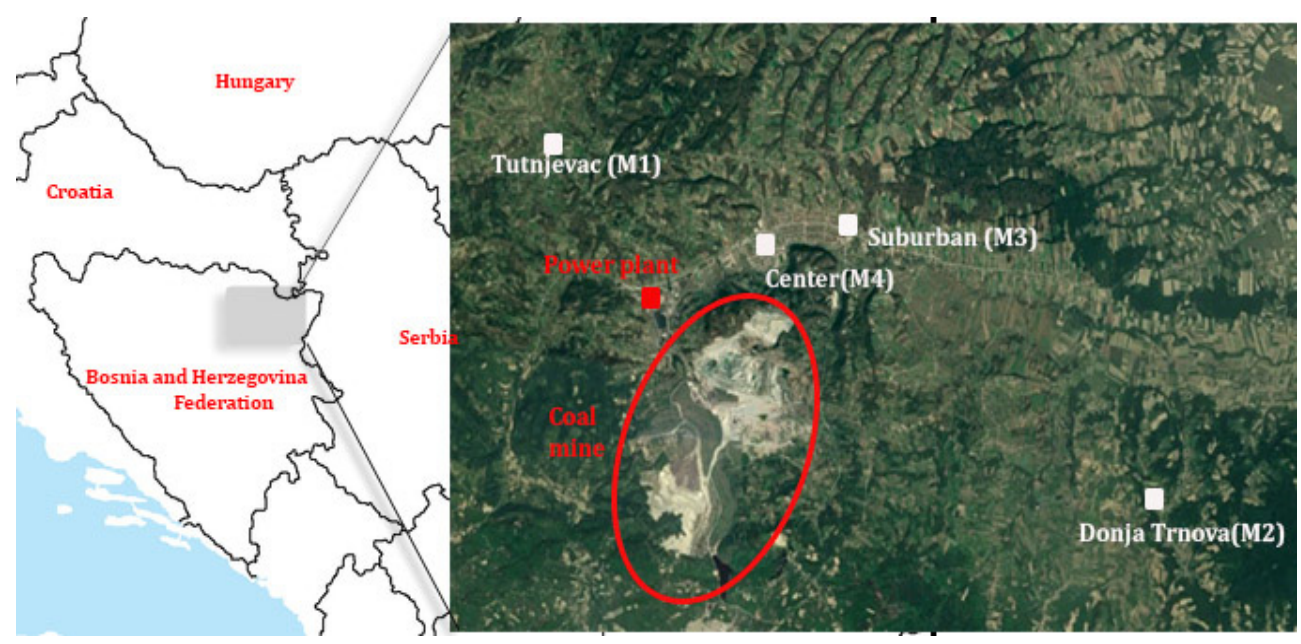

Figure 9. Analyzed site domain and position of measurement sites

\section{Measurement sites}

The In-situ measurements of concentration levels of the relevant parameters were carried out at four locations. Indicative measurements of ambient air quality were carried out at four measuring points [13]. Monitoring was conducted during the thirty days in each of the three campaigns: I spring, II - autumn and III - winter. At automatic station located at city center (M3), the hourly values of meteorological parameters and pollutants during each campaign were conducted. At the remaining three sites (M1, M2 and M3) the measurement of daily particulate concentration was being carried out successively for seven days during each campaign.

The position and distance from the locations and the analyzed pollution source are shown in Figure 9 and Table 1. 
BOGDANA VUJIĆ, VASILE PODE, JELENA MIĆIĆ, FRANCISC POPESCU, UNA MARČETA, ADRIAN EUGEN CIOABLA

\section{Measurement methods}

Measurement of air pollutants, as well as weather conditions, were provided by two types of instruments (Table 1).

Table 1. Specification of methods, monitoring sites and parameters

\begin{tabular}{|c|c|c|c|c|}
\hline Equipment & $\begin{array}{c}\text { Measurement } \\
\text { site abb. }\end{array}$ & $\begin{array}{c}\text { Measurement } \\
\text { site location }\end{array}$ & $\begin{array}{c}\text { Distance } \\
\text { from point } \\
\text { source }(\mathrm{km})\end{array}$ & Parameters \\
\hline \multirow{3}{*}{$\begin{array}{l}\text { Baghirra } \\
\text { instrument for } \\
\text { PM sampling }\end{array}$} & M1 & \begin{tabular}{|l|} 
N44.717353, \\
E18.930450
\end{tabular} & 4.9 & \multirow{3}{*}{$\begin{array}{l}\text { PM } 2.5 \\
\text { PM10 }\end{array}$} \\
\hline & M2 & $\begin{array}{l}\text { N44.664258, } \\
\text { E19.084668 }\end{array}$ & 9.6 & \\
\hline & M3 & $\begin{array}{l}\text { N44.694987, } \\
\text { E19.012171 }\end{array}$ & 3.6 & \\
\hline $\begin{array}{l}\text { Air Pointer } \\
\text { Instrument } \\
\text { (RECORDUM) }\end{array}$ & M4 & $\begin{array}{l}\text { N } 44 \text { 41.496' } \\
\text { E } 18 \text { 59.783' }\end{array}$ & 2.5 & $\begin{array}{l}\text { wind speed (WS), } \\
\text { wind direction } \\
\text { (WD), atmospheric } \\
\text { pressure (P), } \\
\text { relative humidity } \\
\text { (RH) and dew point } \\
\text { (Dew), PM10 }\end{array}$ \\
\hline
\end{tabular}

Air-pointer, located at M4, has a PM10 analyzer that works based on nephelometry optical technique that uses a light-scattering photometer with a silicon detector hybrid preamplifier and a source reference detector. The light scattered is proportional to the particle concentration. This is the fastest particle concentration measurement with high precision and very low detection limit.

At other measuring sites (M1-M3), after passive sampling, the content of PM10 and PM2.5 was determined in a laboratory using gravimetric method (SRPS EN 12341).

\section{ACKNOWLEDGMENTS}

This research is financially supported by the Municipality of Ugljevik, Bosnia and Herzegovina. 


\section{PRELIMINARY ASSESSMENT OF PARTICULATE CONCENTRATION \\ NEAR COAL FIRED POWER PLANT}

\section{REFERENCES}

1. World Health Organization, Health Effects of Particulate Matter, 2013.

2. I.P.S. Araujo; D.B. Costa; R.J.B. De Moraes; Sustainability, 2014, 6, 7666-7688.

3. S.A. Mohd Din; N.N.H. Nik Yahya; A. Abdullah; Procedia - Social Behavioral Sci., 2013. 85, 92 - 99.

4. Z. Wang; C. Zhang; G. Lv; X. Sun; N. Wang; Z. Li; Int. J. Mol. Sci. 2019, 20, 3746 .

5. B. Jiang; D.Xia; X. Zhang; Sci Total Environ. 2018, 616-617, 1414-1422.

6. S. Hu Lee; H. Gordon; H. Yu; K. Lehtipalo; R. Haley; Y. Li; R. Zhang; J Geograph. Res.: Atmosph., 2019, 124, 7098-7146.

7. S. Mohankumara, P. Senthilkumarb; Renew. Sus. Energ. Rev., 2017, 80, 12271238.

8. I.A. Chereches; I. Petean; G.A. Paltinean; A. Mocanu; L. Muresan; G.Arghir; M. Tomoaia-Cotisel; Studia UBB Chemia, 2018, 63, 159-166.

9. Z. Ma; Z. Li; J. Jiang; J. Deng; Z. Yu; S. Wang; L. Duan; Aerosol Air Qual. Res., 2017, 17, 636-643.

10. EIA, Institute for construction, Banja Luka, 2016.

11. B. Stojanović; S.Đukić; Međunarodna konferencija "Elektrane 2014", Zlatibor, 2014.

12. M. Holland; Technical report on goal fired power plants impact on health in West Balcan, Health and Environmental Alliance, Brussels, Belgium; 2016, pp 16-23 (in Serbian).

13. Directive 2008/50/EC, Official Journal of the European Union, 2008.

14. FHMS Jugoslavije, Meteorološki godišnjaci I, 1961-1985.

15. RHMS RS, FHMI FBiH. Dokumentacija 1986-1990.

16. G. Xu; L. Jiao; B. Yhang; S. Yhao; M. Yuan; Y. Gu; J. Liu; X. Tang; Aerosol Air Qual. Res., 2017, 17, 741-751

17. N. Sugimoto; A. Shimizu; I. Matsui; M. Nishikawa; Particuology, 2016, 28, 114-120.

18. B. Vujić; A. Pavlović; G. Vujić; D. Jevtić; Rev.Chim., 2010, 61, 991-997.

19. V. Valverde; M.T. Pay; J.M. Baldasano; Sci. Total Environ., 2016, 541, 701-713.

20. BHAS 2013 - Agency for Statistics of Bosnia and Herzegovina, 2013.

21. Z. Milovanović; V. Sijacki-Zeravcic; D. Milanovic; S. Borojevic; In book: Prijedlog mjera $i$ aktivnosti na uvođenju optimalnog upravljanja pokazateljima konkurentnosti energetskih I procesnih postrojenja (uvođenje ASSET MANAGEMENT-a na najvišem nivou) - faza I, Edition: I, Chapter: IV Modul I, 2009, Publisher: Univerzitet u Banjoj Luci, Mašinski fakultet, Banja Luka, Bosnia and Herzegovina. 
